\title{
RESEARCH
}

\section{Career Attitude of Employees Influencing Work Engagement: Study of Indian Chemical Industries}

\section{Sangeeta Sahu}

\section{ABSTRACT}

\section{KEY WORDS}

\section{Career Attitude}

Self-directed Attitude

Value Driven Attitude

Psychological Mindset Attitude

Work Engagement
In this study, influence of career attitude of employees on work engagement is examined. Structural equation modeling was used on a sample of 444 executives from Chemical industries for analysis. Results show that selfdirected career attitude contributes significantly towards work engagement. The influence of value driven career attitude was not significant and psychological mindset career attitude was negatively related to work engagement. This finding has implications for organizations in planning recruitment and HR strategies for employees.

THE EVOLUTION OF GLOBAL ECONOMY, characterized by organizational restructuring and economic uncertainty has brought changes in traditional organizational career, it has become more unpredictable (Arthur, Khapova and Wilderom, 2005; Dries, Pepermans and Carlier, 2008). Researchers argue that globalization will cause self-expression values to be more evident in employee behaviour (Pettersson, 2003). Various cross-cultural studies with different variables show that culturespecific tendencies play a role in the enactment of careers (Chudzikowski, 2012) and highlighted the need to examine the influence of globalization on career aspects of people in different parts of the world (Kats, Van Emmerik, Blenkinsopp, and Khapova 2010). Though studies have been conducted with samples from U.S. and U.K., few such studies are in Indian context (Budhwar and Baruch, 2003).

To gain competitive edge organizations are working on engagement as one of the key element in their growth strategy. It is looked upon by the organizations as a way to increase productivity and retain employees. Survey by consultants on employee engagement shows only 13 percent of employees across 142 countries are engaged in theirjobs (Gallup consultant's report, 2013). To raise engagement at workplace, it is imperative to divulge the factors influencing it. The employees selected through hiring process carry their attitude to workplace, of which, self-efficacy is related to work engagement (Xanthopoulou, Bakker, Demerouti, \& Schaufeli, W. B., 2009; Chaudhary et al, 2012). This paper focuses on work engagement of middle level executives employed in Chemical Industries, India. Indian Chemical Industry contributes six percent to Indian GDP and accounts for 13 percent of exports (Spurting the growth of Indian Chemical Industry, India Chem 
2014). Its growth in recent years is attributed to product customization and understanding of unique customer needs (ASSOCHAM, 2014). It needs competent and engaged employees. Substantial research in the past decade have shown that employees when engaged, service quality, customer satisfaction, productivity and financial results of the organization improve (Harter, Schmidt and Hayes, 2002; Bakker and Schaufeli, 2008).

An approach towards alignment of individual goal and organization objective paves the way of success for both. On one side, career of an employee is development through experience and jobs that may be in one or more organizations (Baruch and Rosenstein, 1992); whereas, on the other side, an organization works on engaging its people through various interventions in order to accomplish its objective and retain them. Therefore, it is important to consider employee viewpoint for developing interventions to engage them. Existing literature on career is focused on protean and boundaryless career (Arthur and Rousseau, 1996; Hall, 1996; Arnold and Cohen, 2008; Briscoe et al., 2006, Volmer and Spurk, 2010; Bruin and Buchner, 2010). They have defined the two attitudes, developed scale to measure it and also raised various issues to be researched out in the changing business environment.

As a consequence of restructuring in organizations to compete the forces of globalization, employees shift has been observed from the traditional or organizational career to the protean career (Bruin and Buchner, 2010). But many US and UK researchers talk of prevalence and appeal of boundaryless careers among the employees (Dries, 2011). These contradictory views are due to difference in cultural and contextual forces affecting career decisions. In dearth of such studies in Indian context, proposed research will make an attempt to fill the gap.

\section{Work Engagement}

Work engagement has been conceptualized in the light of different organizational behavior literature by many researchers. It is defined as a positive, fulfilling, work-related state of mind characterized by vigor, dedication, and absorption (Schaufeli and Bakker, 2004). Vigor is marked by high levels of energy and mental resilience while working. Dedication refers to strong involvement in one's work and experience a sense of significance, enthusiasm, and challenge. Absorption is described by being fully concentrated and happily engrossed in one's work. Another multidimensional concept explains engagement through three energies that result in performance; they are physical, emotional and cognitive component (Rich, LePine, and Crawford, 2010; May, Gilson, and Harter, 2004). Physical energy at work contributes in fulfilling organizational goals in terms of behavior exhibited in the form of individual effort. Cognitive energy promotes vigilant, attentive, and focused behavior leading to performance, and emotional energy is evident in organization citizenship behavior of the employee (Kahn, 1990; Rich et al., 2010).

Scarce research available on antecedents explaining engagement makes it difficult to map its nomological network. Hence, there is need to theoretically and empirically explore potential antecedents of engagement as highlighted in many studies (Macey and Schneider, 2008; Christian, Garza, and Slaughter, 2011). This paper accentuates on the factors at work place and individual attitude leading to work engagement.

Search for a strong unifying theory to explain the phenomena of engagement in domain of the psychological and behavioural constructs lead to further exploration through self-determination theory (SDT). It is based on motivation to understand the underlying psychological mechanism through autonomous regulation (Meyer and Gagne,2008). SDT explained extrinsic motivation in three different forms, of which 
attaining a valued personal goal (identification) and expressing one's sense of self (integration) are referred as autonomous regulation. The role of intrinsic motivational orientation was observed among the engaged employee performing tasks of their interest (Amabile, Hill, Hennessey, and Tighe, 1994). Hence assuming career goals being of value to the individual and its attainment as a form of expressing oneself, the relation of career attitude on engagement can be explained in the light of SDT.

Studies conceptualizing engagement noted high level of energy exerted by the engaged employees in their job (Macey and Schneider, 2008). Empirical results show engagement is positively related to customer satisfaction (Salanova, Agut, and Peiro, 2005), in-role and extra-role performance (Schaufeli, Taris, and Bakker, 2006), and financial returns (Xanthopoulou, Bakker, Demerouti, and Schaufeli, 2009). Engaged employees display activities like active participation, believe in themselves, generate own positive feedback and their values have been found to match that of the organization (Salanova, Llorens, and Schaufeli, 2011). Therefore, researchers have emphasized on the need to expand research on factors leading to engagement at work (Christian, Garza, and Slaughter, 2011).

\section{Career Attitude}

Career is defined as "the evolving sequence of a person's work experiences over time" (Arthur, Hall, and Lawrence, 1989). Traditionally careers were defined by employer-employee relationship, whereas, present-day career is influenced by many contextual factors, such as socio-political environment, economy, culture and personal factors (Sullivan and Baruch, 2009; Greenhaus, Callanan, and DiRenzo, 2008). Though intention to change career or career aspirations mainly depend on the attitude of the employee, it is built on perceptions from interaction of individual with the environment (Muja and Appelbaum, 2012).
Sullivan and Baruch's (2009) discourse on transition in career orientation from traditional to contemporary career paths inveigled by technological, global and social changes captures the conceptualization of different career constructs. Boundaryless (DeFillippi and Arthur, 1994) and protean (Hall, 2004) concept of career emerged in response to the changing structure of business organizations. These two concepts have dominated career research in last decade. Studies show that protean and boundaryless constructs vary across career stage and context implying that they are attitudes (Briscoe, Hall, and DeMuth, 2006; Briscoe, Henagan, Burton, and Murphy, 2012).

The protean career attitude introduced by Hall (2004) describes those who are flexible and adaptive to change. Protean career is defined "as a career in which the person is 1) value-driven in the sense that the person's internal values provide the guidance and measure of success for individual's career; and 2) self-directed in personal career management which means having the ability to be adaptive in terms of performance and learning demands" (Briscoe and Hall, 2006,p.8). People with protean career attitude are self- directed driven by their inner values. These individuals take the responsibility for own career growth (Hall, 2004; Sullivan and Arthur, 2006).

The boundaryless career concept talks about a person whose mindset, "navigates the changing work landscape by enacting a career characterized by different levels of physical and psychological movement" (Sullivan and Arthur, 2006, p.19). The concept was developed by DeFillippi and Arthur (1994), they highlighted on mobility preference of these employees. It refers to an individual's mental and physical preparedness for jobs across the organizational or departmental boundaries. They feel energized on the opportunity to experience new environment and people. Engaged employees possess self-efficacy that helps them to control the 
environment and achieve career success (Luthans, Norman, Avolio, and Avey, 2008) and has been found to influence early phases of an individuals' career choice (Betz and Hackett, 2006).

\section{Career Attitude and Engagement}

Career management systems in India point towards plethora of choices available with organizations in developing employee career and the importance of organizational climate in the process (Budhwar and Baruch, 2003). Such resources focused on career development are assumed to make the employee more engaged at work. Research demonstrates that self-directed career attitude helps in engaging employees (Segers et al. 2008). A cluster analysis conducted by them to observe matching of work motives to the protean and boundaryless career attitude provides support to the logic that an individual will put more effort towards fulfillment of motives by higher level of engagement behavior at work. Hence, it is important that the individual career motive protean or boundaryless if supported by the organization context will lead to engagement at work.

Another research to study coping strategies in conditions of economic recession with career attitudes show that protean and boundaryless correlate differently with work outcomes (Briscoe, et al., 2012). Their SEM results suggested full mediation by coping strategy on the relation of boundaryless career attitude with performance, career success and psychological well-being; partial mediation was seen between protean career attitude and the outcomes. The relation of boundaryless with psychological well-being was negative but positive for protean career. From this it can be interpreted that career attitude will influence work engagement differently. Hence, the proposed hypotheses are;

$\mathrm{H} 1$ : Person high in self-directed career attitude will exhibit increased level of engagement at work. $\mathrm{H} 2$ : Person high in value driven career attitude will exhibit increased level of engagement at work
H3: Person high in psychological mindset of boundaryless career attitude will exhibit low level of engagement at work.

\section{Methods}

\section{Participants}

Respondents included 444 middle and lower level managers from Chemical industries in the state of Gujrat, India. The data was collected during mid of December, 2014 to January, 2015. The response was collected on bilingual questionnaires (statements were both in English and Gujrati) on pen and paper. The bilingual format of questionnaire was passed through two rounds of experts advise for appropriateness of language and meaning of the sentences converted in Gujrati language before administering to the sample. 600 questionnaires were distributed by purposive sampling, of which 504 filled in questionnaires were received. Response rate was 84 percent. After initial inspection only 444 completely filled questionnaires were considered for further analysis. Rejection rate was 13 percent. The 444 questionnaires were finally used for Structural Equation Modeling as the sample size is more than 200 (Kline, 2011; Shah and Goldstein, 2006).

Majority of participants were male (84\%). Their mean age was 35 years $(\mathrm{SD}=7.49)$. The ratio of professionally educated to non-professionally qualified degree holders is $2: 3$ among the executives. Professionally qualified include those with Management, Engineering, and such degrees, whereas non-professionally qualified hold a graduate/postgraduate degree from college.

\section{Measures}

The four variables 'self directed'(sd) and 'value directed'(vd) attitude of protean career, 'psychological mindset'(ms) of boundaryless career and work engagement (we) were studied using structured and standardized questionnaire. Protean career attitude of managers was measured using protean career scale with eight items for self- 
directed attitude and six items for value driven. The boundaryless career scale with eight items for psychological mindset developed by Briscoe and associates (Briscoe, Hall, and DeMuth, 2006) was administered. 'Work engagement' was measured with the Utrecht Work Engagement Scale (UWES, reduced version by Seppala, Mauno, Feldt, Hakanen, Kinnunen, Tolvanen, and Schaufeli, 2009), consisting of 9 items.

\section{Procedure}

In the first phase of data analysis, mean, standard deviation, Pearson correlation and Cronbach alpha was calculated for all variables using SPSS as given in Table 1. Reliability (cronbach alpha) of the measurement scales is more than 0.7; greater than 0.7 is acceptable for further analysis (Nunnally and Bernstein, 1994). The correlation value of demographic variables like age and experience with other latent factors is low; therefore, demographic variables were not taken for further analysis in the nomological network.

Table 1: Descriptive statistics, Pearson's correlation coefficients, Cronbach alpha reliability, composite reliability and AVE.

\begin{tabular}{|c|c|c|c|c|c|c|c|c|c|c|c|c|c|}
\hline $\begin{array}{l}\text { Sl. } \\
\text { No. }\end{array}$ & Variables & Mean & 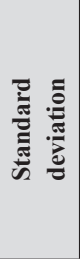 & 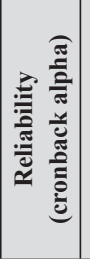 & 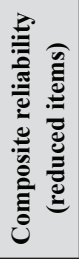 & 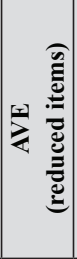 & 1 & 2 & 3 & 4 & 5 & 6 & 7 \\
\hline 1 & Age & 35.41 & 7.49 & - & - & - & 1 & & & & & & \\
\hline 2 & Orgnization experience & 5.79 & 4.34 & - & - & - & $.212^{* *}$ & 1 & & & & & \\
\hline 3 & Total experience & 9.58 & 6.14 & - & - & - & $.473^{* *}$ & $.608^{* *}$ & 1 & & & & \\
\hline 4 & Self-directed & 33.37 & 3.78 & $(.79)$ & .68 & .52 & $.164^{* *}$ & $.112^{*}$ & .047 & 1 & & & \\
\hline 5 & Value driven & 24.36 & 3.25 & $(.75)$ & .71 & .55 & .071 & .043 & -.006 & $.638^{* *}$ & 1 & & \\
\hline 6 & Mindset & 33.03 & 3.72 & $(.75)$ & .67 & .50 & .073 & .029 & -.047 & $.621^{* *}$ & $.648^{* *}$ & 1 & \\
\hline 7 & Work engagement & 42.04 & 9.66 & $(.73)$ & .82 & .69 & $.251^{* *}$ & $.219^{* *}$ & .092 & $.591^{* *}$ & $.447^{* *}$ & $.477^{* *}$ & 1 \\
\hline \multicolumn{14}{|c|}{$\begin{array}{l}\text { **. Correlation is significant at the } 0.01 \text { level (2-tailed) } \\
\text { *. Correlation is significant at the } 0.05 \text { level (2-tailed) } \\
\text { Average Variance Extracted (AVE) }\end{array}$} \\
\hline
\end{tabular}

The second phase is subdivided into two-stage approach with confirmatory factor analysis (CFA) and structural equation modeling $(\mathrm{SEM})(\mathrm{Hu}$ and
Bentler, 1999; Byrne and De Vijver, 2010). An exploratory factor analysis (EFA) was conducted to identify cross-loading items. These items were dropped from the original scale based on their loadings. The composite reliability (CR) and average variance extracted (AVE) given in Table 1 clearly shows that CR of 'value driven' and 'work engagement' is $>0.70$ meeting the acceptability criteria. For 'self-directed' and 'mindset' CR is slightly less than 0.70. Moreover, AVE of all the scales is acceptable with $=>0.50$. It also checks for discriminant validity. CFA was performed to establish the distinctness of the measures in the model proposed. It was found that all the variables are distinct from each other. The structural model was analyzed in the second step.

The results of CFA $\left[\chi^{2}=71.41, \mathrm{n}=444 ; \chi 2 / \mathrm{df}=\right.$ $3.40 ; \mathrm{CFI}=0.97 ; \mathrm{NFI}=0.96$; $\mathrm{GFI}=0.97$; $\mathrm{RMSEA}=$ $0.07]$ meets the criteria for model fit. As suggested by Kline (2005) that CFI and other incremental fit indices are above 0.90 for satisfactory model fit. In addition RMSEA value also indicated reasonable fit. RMSEA values 0.05 or less indicate close fit; 0.05 to 0.08 indicate reasonable fit, and values 0.08 to 0.10 indicate marginal fit (Browne and Cudeck, 1992). The chi-square statistic was significant, which can be expected with larger sample sizes (Bagozzi \& Yi, 1988; Hair, Black, Babin, Anderson, \& Tatham, 2006).

Hypothesis was tested through the model shown in Figure 1. Results of structuralequationmodeling (SEM) demonstrated that career attitudes in form of 'self-directed', 'value driven' and 'mindset' (exogenous variable) differently correlated with the work engagement (endogenous variable). The hypothesized model 
tested by SEM $[\chi 2=71.41, \mathrm{n}=444, \mathrm{p}<.000 ; \chi 2 / \mathrm{df}$ $=3.40 ; \mathrm{CFI}=0.97 ; \mathrm{NFI}=0.96 ; \mathrm{GFI}=0.97$; IFI $=$ 0.97; TLI $=0.95 ;$ RMSEA $=0.07]$. The fit indices are closer to 1 . The model fits the data (Raykov and Marcoulides, 2000, Hoyle, 1995).

Table 2: Parameter estimates.

\begin{tabular}{|c|c|c|c|}
\hline $\begin{array}{c}\text { Structural } \\
\text { relationships }\end{array}$ & $\begin{array}{c}\text { Unstandardized } \\
\text { parameter } \\
\text { estimates }\end{array}$ & $\begin{array}{l}\text { Standardized } \\
\text { parameter } \\
\text { estimates }(\beta)\end{array}$ & $\mathbf{R}^{2}$ \\
\hline we & $1.93 * * *$ & $.721 * * *$ & .40 \\
\hline we & .134 (ns) & .059 (ns) & \\
\hline $\mathrm{ms}$ & $-.541(\mathrm{~ns})$ & $-.185(\mathrm{~ns})$ & \\
\hline
\end{tabular}

Figure 1 depicts the structural equation model with respect to the postulated hypotheses. Supporting Hypothesis 1 self-directed (sd) career attitude of employees significantly contributes positively in work engagement $(\beta=.721 ; p<0.0001)$. Hypotheses $2 \& 3$ are not completely supported by the study. $\mathrm{H} 2$ shows very low positive relation between value driven attitude of employee and their work engagement ( $\beta=.059$; ns). H3 shows a negative relation between mindset and work engagement but the relation is not significant $(\beta=$ -.185; ns). The contribution of career attitude of employees in explaining their work engagement is evident in Figure1. Career attitude explains 40 percent of total variance (R2) in work engagement. Figure 1: Structural equation model of career attitude and work engagement.

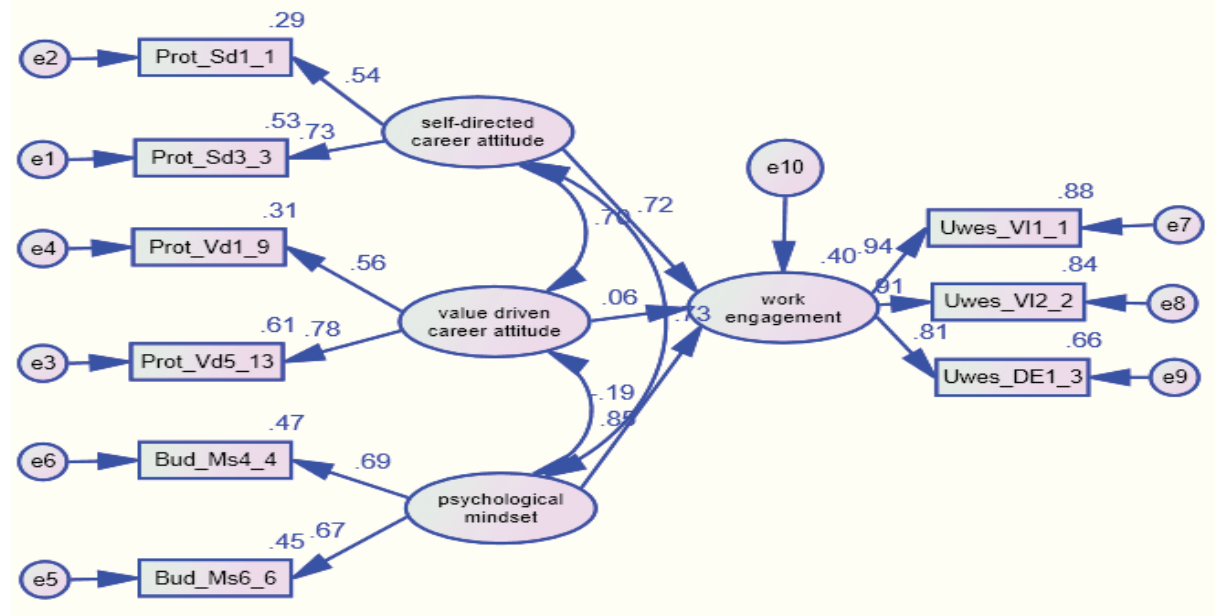

\section{Discussion and Implications}

In the contemporary career era, self-directed career attitude is seen as an important factor leading to work engagement. The findings of this study are supported by self determination theory (SDT) and job demand-resource model (JD-R) (Deci and Ryan, 1985; Xanthopoulou, Bakker, Demerouti, and Schaufeli, 2007). Hypothesis 1 is supported by the model that explains significant role of selfdirected attitude in work engagement behaviour of employee. The concept of autonomous regulation derived from ones' personal goal and expressing self is associated with engagement. It leads to passion, higher levels of performance, persistence, initiative, and creativity (Ryan and Deci, 2000). Moreover, personal resources like self-efficacy, self-esteem and optimism influence work engagement (Xanthopoulou et al., 2007). Selfdirected career attitude of employee on retirement intentions through self-management behaviour supports the present finding (Vos and Segers, 2013). Hence, organizations can cater to protean careerists with self-directed attitude through challenging job assignments; developmental relationships with boss and peer; formal training and education; and information about future opportunities (Hall, 2004).

Value driven career attitude and psychological mindset do not influence work engagement. Employees with psychological mindset show negative relation with engagement. Those high in psychological mobility will be searching for avenues external to their work that leads against the concept of engagement.

This study has some shortcomings. First, it is a cross-sectional study; the data was collected one time, hence causal relationship of self-efficacy on career attitude and engagement 
is restricted. Second, this study was exclusively based on self-reported measures that might lead to common method variance problem, though author carried out possible procedural and some statistical remedies, still the variance problem cannot be completely ruled out. Such studies that measure self-efficacy, individual career attitude and work engagement have to be self-reported (Makikangas et al., 2004).

\section{REFERENCES}

Amabile, T. M., Hill, K. G., Hennessey, B. A., \& Tighe, E. M. (1994). The Work Preference Inventory: assessing intrinsic and extrinsic motivational orientations. Journal of Personality and Social Psychology, 66(5), 950- 967.

Arnold, J., \& Cohen, L. (2008). 1 The Psychology of Careers in Industrial and Organizational Settings: A Critical But Appreciative Analysis. International review of industrial and organizational psychology, 23(1), 1-44.

Arthur, M. B., \& Rousseau, D. M. (1996). The boundaryless career. Oxford University Press.

Arthur, M. B., Hall, D. T., \& Lawrence, B. S. (Eds.). (1989). Handbook of career theory (pp.8-9). Cambridge University Press.

Arthur, M. B., Khapova, S. N., \& Wilderom, C. P. (2005). Career success in a boundaryless career world. Journal of organizational behavior, 26(2), 177-202.

Bagozzi, R. P., \& Yi, Y. (1988). On the evaluation of structural equation models. Journal of the academy of marketing science, 16(1), 74-94.

Bakker, A. B., \& Demerouti, E. (2008). Towards a model of work engagement. Career development international, 13(3), 209-223.
Third, the sample in present study represented executives from few organizations of one industry. To validate the findings similar study needs to be carried out in other industries. Finally, factors influencing the relationship of career attitude and work engagement can be explored. The role of culture in determining the attitude and work engagement also needs to be studied.

Baruch, Y., \& Rosenstein, E. (1992). Human resource management in Israeli firms: planning and managing careers in high technology organizations. International Journal of Human Resource Management, 3(3), 477-495.

Betz, N. E., \& Hackett, G. (2006). Career selfefficacy theory: Back to the future. Journal of Career Assessment, 14(1), 3-11.

Briscoe, J. P., \& Hall, D. T. (2006). The interplay of boundaryless and protean careers: Combinations and implications. Journal of Vocational Behavior, 69(1), 4-18.

Briscoe, J. P., Hall, D. T., \& Frautschy DeMuth, R. L. (2006). Protean and boundaryless careers: An empirical exploration. Journal of Vocational Behavior, 69(1), 30-47.

Briscoe, J. P., Henagan, S. C., Burton, J. P., \& Murphy, W. M. (2012). Coping with an insecureemployment environment:

The differing roles of protean and boundaryless career orientations. Journal of Vocational Behavior, 80(2), 308-316.

Budhwar, P. S., \& Baruch, Y. (2003). Career management practices in India:an empirical study. International Journal of Manpower, 24(6), 699-719. 
Byrne, B. M., \& van De Vijver, F. J. (2010). Testing for measurement and structural equivalence in large-scale cross-cultural studies: Addressing the issue of nonequivalence. International Journal of Testing, 10(2), 107-132.

Chaudhary, R., Rangnekar, S., \&Barua, M. K. (2012). Relationships between occupational self-efficacy, human resource development climate, and work engagement. Team Performance Management, 18(7/8), 370-383.

Christian, M. S., Garza, A. S., \& Slaughter, J. E. (2011). Work engagement: A quantitative review and test of its relations with task and contextual performance. Personnel Psychology, 64(1), 89-136.

Chudzikowski, K. (2012). Career transitions and career success in the 'new' career era. Journal of Vocational Behavior, 81(2), 298306.

De Bruin, G. P., \& Buchner, M. (2010). Factor and item response theory analysis of the Protean and Boundaryless Career Attitude Scales. SA Journal of Industrial Psychology, 36(2), $1-11$.

Deci, E. L., \& Ryan, R. M. (1985). The general causality orientations scale: Selfdetermination in personality. Journal of research in personality, 19(2), 109-134.

DeFillippi, R. J., \& Arthur, M. B. (1994). The boundaryless career: A competency-based perspective. Journal of Organizational Behavior, 15(4), 307-324.

Dries, N. (2011). The meaning of career success: Avoiding reification through a closer inspection of historical, cultural, and ideological contexts. Career Development International, 16(4), 364-384.
Dries, N., Pepermans, R., \& De Kerpel, E. (2008). Exploring four generations' beliefs about career: Is "satisfied" the new "successful"?. Journal of Managerial Psychology, 23(8), 907-928.

Greenhaus, J. H., Callanan, G. A., \& DiRenzo, M. (2008). A boundaryless perspective on careers. In J. Barling \& C.L. Cooper (Eds.), In J. Barling \& C.L. Cooper (Eds.), The Sage Handbook of Organizational Behavior Volume One: Micro Approaches (pp.277279), Sage Publications.

Hair, J. F., Black, W. C., Babin, B. J., Anderson, R. E., \& Tatham, R. L. (2006). Multivariate data analysis (Vol. 6). Upper Saddle River, NJ: Pearson Prentice Hall.

Hall, D. T. (2004). The protean career: A quartercentury journey. Journal of vocational behavior, 65(1), 1-13.

Harter, J. K., Schmidt, F. L., \& Hayes, T. L. (2002). Business-unit-level relationship between employee satisfaction, employee engagement, and business outcomes: a metaanalysis. Journal of applied psychology, 87(2), 268-279.

Hu, L. T., \& Bentler, P. M. (1999). Cutoff criteria for fit indexes in covariance structure analysis: Conventional criteria versus new alternatives. Structural equation modeling: a multidisciplinary journal, 6(1), 1-55.

Kahn, W. A. (1990). Psychological conditions of personal engagement and disengagement at work. Academy of management journal, 33(4), 692-724.

Kats, M. M., Van Emmerik, I. H., Blenkinsopp, J., \&Khapova, S. N. (2010). Exploring the 
associations of culture with careers and the mediating role of HR practices: A conceptual model. Career Development International, 15(4), 401-418.

Luthans, F., Norman, S. M., Avolio, B. J., Avey, J. B. (2008). The Mediating Role of Psychological Capital in the Supportive Organizational Climate - Employee Performance relationship. Journal of Organizational Behavior, 29(2), 219 - 238.

Macey, W. H., \& Schneider, B. (2008). The meaning of employee engagement. Industrial and organizational Psychology, 1(1), 3-30.

Mäkikangas, A., Kinnunen, U., \& Feldt, T. (2004). Self-esteem, dispositional optimism, and health: Evidence from cross-lagged data on employees. Journal of research in personality, 38(6), 556-575.

May, D. R., Gilson, R. L., \& Harter, L. M. (2004). The psychological conditions of meaningfulness, safety and availability and the engagement of the human spirit at work. Journal of occupational and organizational psychology, 77(1), 11-37.

Meyer, J. P., \& Gagne, M. (2008). Employee engagement from a self-determination theory perspective. Industrial and Organizational Psychology, 1(1), 60-62.

Muja, N., \& Appelbaum, S. H. (2012). Cognitive and affective processes underlying career change. Career Development International, 17(7), 683-701.

Nunnally J. and Bernstein (1994). Psychometric theory. McGraw Hill, New York.

Pettersson, T. (2003). The relations between religion and politics in the contemporary
Western world: The impact of secularization, post modernization and peoples' basic value orientations. Available at: www. worldvaluessurvey.org

Rich, B. L., Lepine, J. A., \& Crawford, E. R. (2010). Job engagement: Antecedents and effects on job performance. Academy of management journal, 53(3), 617-635.

Ryan, R. M., \& Deci, E. L. (2000). Selfdetermination theory and the facilitation of intrinsic motivation, social development, and well-being. American psychologist, 55(1), 68-78.

Salanova, M., Agut, S., \& Peiró, J. M. (2005). Linking organizational resources and work engagement to employee performance and customer loyalty: the mediation of service climate. Journal of Applied Psychology, 90(6), 1217.

Salanova, M., Llorens, S., \& Schaufeli, W. B. (2011). "Yes, I can, I feel good, and I just do it!" On gain cycles and spirals of efficacy beliefs, affect, and engagement. Applied Psychology, 60(2), 255-285.

Schaufeli, W. B., \& Bakker, A. B. (2004). Job demands, jobresources, and their relationship with burnout and engagement: A multisample study. Journal of organizational Behavior, 25(3), 293-315.

Schaufeli, W. B., Taris, T. W., \& Bakker, A. B. (2006). Doctor Jekyll or Mr Hyde? On the differences between work engagement and workaholism. In R. Burke (Ed.), Workaholism and long working hours (pp. 193 217) . Cheltenham: Edward Elgar. 
Segers, J., Inceoglu, I., Vloeberghs, D., Bartram, D., \& Henderickx, E. (2008). Protean and boundaryless careers: A study on potential motivators. Journal of Vocational Behavior, 73(2), 212-230.

Seppälä, P., Mauno, S., Feldt, T., Hakanen, J., Kinnunen, U., Tolvanen, A., \& Schaufeli, W. (2009). The construct validity of the Utrecht Work Engagement Scale: Multisample and longitudinal evidence. Journal of Happiness Studies, 10(4), 459-481.

Sullivan, S. E., \& Arthur, M. B. (2006). The evolution of the boundaryless career concept: Examining physical and psychological mobility. Journal of Vocational Behavior, 69(1), 19-29.

Sangeeta Sahu is an Associate Professor in the Human Resource Management at Purvanchal University, India. She has a long experience in teaching and research. She published a number of research papers in various national and international
Volmer, J., \& Spurk, D. (2011). Protean and boundaryless career attitudes: relationships with subjective and objective career success. Zeitschrift für ArbeitsmarktForschung, 43(3), 207-218.

Xanthopoulou, D., Bakker, A. B., Demerouti, E., \& Schaufeli, W. B. (2009). Reciprocal relationships between job resources, personal resources, and work engagement. Journal of Vocational Behavior, 74(3), 235244.

Xanthopoulou, D., Bakker, A. B., Demerouti, E., \& Schaufeli, W. B. (2007). The role of personal resources in the job demandsresources model. International Journal of Stress Management, 14(2), 121-141.

journals. She holds a Ph.D. degree too. Her area of interests in research includes performance drivers, organization commitment, employer branding, employee engagement, career, work engagement mainly in service and manufacturing organizations.

e-mail: sangeeta_hrd@yahoo.co.in 